\title{
To evaluate the performance of online learning in primary school when pandemi covid-19 in rantau panjang sub district with cipp model
}

\author{
Irzan Irzan ${ }^{1}$, Syarwani Ahmad ${ }^{2}$, Achmad Wahidy ${ }^{3}$ \\ ${ }^{1}$ SDN 01 Rantau Panjang Ogan Ilir \\ ${ }^{2}$ Universitas PGRI Palembang
}

\begin{tabular}{|c|c|}
\hline Article Info & ABSTRACT \\
\hline Article history: & This study attempts to describe the evaluation of the implementation of online \\
\hline $\begin{array}{l}\text { Received Jul } 12^{\text {th }}, 2021 \\
\text { Revised Aug } 20^{\text {th }}, 2021 \\
\text { Accepted Aug } 30^{\text {th }}, 2021\end{array}$ & $\begin{array}{l}\text { learning when pendemi covid-19 in elementary school, rantau panjang sub- } \\
\text { district, ogan ilir district with cipp model. This study using a qualitative } \\
\text { methodology descriptive. case with the approach. The data collection } \\
\text { techniques used in this research is a questionnaire, interview and } \\
\text { documentation. The data analysis using a method of triangulation and obtain }\end{array}$ \\
\hline Keyword: & $\begin{array}{l}\text { information or data from various sources to verify the data. The research } \\
\text { results be concluded that the implementation of online learning when pendemi }\end{array}$ \\
\hline $\begin{array}{l}\text { Covid-19 } \\
\text { Online learning }\end{array}$ & $\begin{array}{l}\text { covid-19 in elementary school, rantau panjang sub-district, ogan ilir district } \\
\text { with a model cipp was going pretty good. }\end{array}$ \\
\hline
\end{tabular}

(C) 2021 The Authors. Published by IICET.

CIPP

\section{Corresponding Author:}

Irzan Irzan

SDN 01 Rantau Panjang Ogan Ilir

Email: irzan83do@gmail.com

\section{Introduction}

Learning process in education world in indonesia usually held in an educational institution, good image formal school started in basic education, medium to college education, and non-formal institutions such as, early childhood education, community learning activity centers, courses, and others, as well as education informal education happened in family.

The virus corona or more known as the coronavirus penyakit 2019 Covid-19 to the study of harvard medical school was widespread in china since august 2019. The world first health crisis in the global flu pandemic the millennium after spain in 1918 [1]. The the very spread quickly to various countries in the world and Indonesia. As world health organization who virus said the current global pandemic covid-19 as march on 2 indonesia report on a case confirmation covid-19 first and 2 case. Until the date of 12 june 2020 based on update corona in indonesia currently 34.406 who tested positive corona.

Pandemics covid-19 in indonesia affect widely for the sector as the economic sector, social and cultural, tourism and education. Anticipate the transmission of the virus the government has issued policies, as isolation, social and physical distancing (keep at a distance to social restrictions large scale (PSBB). This condition requires residents to keep stay at home, work, serve, consume, And learn at home. The march 24 2020 the central government through of education and culture minister of the republic of indonesia issued 
circular no. 4 the year 2020 on the implementation of the education policy in the emergency the spread of covid-19.In letter explained that the learning process carried out in house s through online / long-distance, carried out to give learning experience meaningful for students. Activity and tasks learning learn from house can be varied antarsiswa, according to their interests and condition Each, including consider gap access /. learning facilities at home

Ogan Ilir district part of the Province Of South Sumatra to affected pandemics covid-19. Ogan Ilir district having sixteen district one of them rantau panjang sib-district. All primary schools in rantau panjang subdistrict ogan ilir district the province of south sumatra to feel the impact of the the spread of the plague covid19. Follow up instruction president of the republic of indonesia and circulars of education and culture minister the republic of indonesia no. 4 the year 2020 on the implementation of the education policy in the emergency the spread of covid-19 , the district government ogan ilir issued circular number: 420 / 400 per sekr / d.dikbud.oi / 2020 date march 272020 about disease prevention corona virus ( covid-19) On a unit. educationIn the letter explained that the whole school Paud, primary school junior high schools and private land $\mathrm{pkbm} \mathrm{/} \mathrm{been} \mathrm{given} \mathrm{to} \mathrm{the} \mathrm{district} \mathrm{government} \mathrm{ogan} \mathrm{ilir} \mathrm{divert} \mathrm{activity} \mathrm{while} \mathrm{learning} \mathrm{from} \mathrm{school.}$ institutions to the house Keep learning effective in the house through a remote class with a system under monitoring of online teachers and parents.

Learning the system change drastically of learning face to face become a lesson in the psychological impact online for schools, teachers and students. Many schools including those residing in rantau panjang sub-district not habitually do learning online were forced to modify the system learning face to face a long distance learning online covid-19 pandemic due to hit indonesia in the midst of limited of existing infrastructure.

Based on a survey early done by researchers, learning with a system of online to cause the learning done be less effective and efficient, teachers sometimes difficulty give the subject matter, school tuition sometimes more terrible the material given teachers, lack of interaction between teachers and school tuition make them terrible the material given, students the more difficult it is ask matter who has not understood and a lack of concentration students if done learning online. System learning online this, gave rise to various the problems faced by either by teachers and students, as the subject matter unfinished delivered then teachers replace with of tasks [2].

Problems by teachers and students in the online learning, not only that there are also technical obstacles other obstacles include: not every student able, equivalent of course this has implications for the, psychology not all teachers are in use the facilities as a media, online learning not all parents have students online media: as well phone hand personal compute, PC tablets and other gadgets, the internet, limited and internet network. Slow All this triggered. online learning to new problems.

Dealing with the above, researchers interested to know the effectiveness of online learning when the pandemic covid-19 on primary schools in Rantau Panjang Ogan Ilir, district it is necessary for your consideration to fix weakneses in the implementation of online learning, so that in the future if applied again learning online system is more effective, efficient, and better quality. 1)Evaluation of the context of context in the implementation of online learning at the time the pandemic covid-19 in elementary school, rantau panjang sub-district, ogan ilir. District, 2) Evaluation of input input in the implementation of online learning at the time the pandemic covid-19 in elementary school, rantau panjang sub-district, ogan ilir. District, 3)Evaluation of the process of ( process ) in the implementation of online learning at the time pandemic covid-19 in elementary school, rantau panjang sub-district, ogan ilir. District ,4) Evaluation of the results of the product of online learning in primary school when pandemic covid-19 in elementary school, rantau panjang sub-district, ogan ilir. District

\section{Method}

This research with qualitative research methods as the procedure research that yields the data in form of descriptive of written or spoken words from people and observed behavior. So, in qualitative research, although the data obtained can be calculated and presented in numbers, the data analysis is qualitative in nature. The subject of the research is all school principles, teachers upper-class (class rooms, IV, V, and VI) and some students upper-class ( students class rooms, IV, V, and VI). Data collection techniques used in this research was, questionnaire, interview and documentation 


\section{Results and Discussions}

The outcome of the findings researchers in the field show that school policy or teacher in applying pembelajan with a system of online determined by a number of factors, among other: 1) The availability of an electronic device for learning online owned by teachers and students. There are still many students in Rantau Panjang who do not have an electronic device (laptop, gawai, a computer ) for online learning process. From the results of the questionnaire only 58 percent of students having gawai online to learn. While teachers also still do not having gatget (smart) a smartphone, there are $86 \%$ gatget with the teachers, it is there are $14 \%$ who do not have. 2) Application availability of media ( whatshapp, online learning zoom, a telegram, google, classroom). With the low availability of an electronic device for learning online of course the application availability of online learning is also a little. Students and teachers who do not have gawai certainly not have applications. online learning. 3) Financial availability. Many people still parents who could not afford to buy the internet and mobile. online to learnThis is of course because the community economic long established not. Seacoast. 4) Unstable internet network. Internet network in Rantau Panjang not stable one cause the weather or something else. For example in the moment networks dead PLN electricity / disconnected so also breaking internet network.

Those four things above is the main factor barrier in online learning in Rantau Panjang sub-district and not all schools in Rantau Panjang sub-district implement online learning system. Online learning can be done because there are supporting factors, such as cell phones, pulse, the quotas and the internet network that is stable and good [3].

Fourth factors should be paid attention together and can be anticipated by all parties including by respondents, parents, school, and the government both central and local government. With computers, laptop, or smartphone could be learning the hold. Students who did not having smartphone can join students who have smartphone or school able to form study groups together and be given assistance laptop or smartphone still supervised teachers and parents and still apply the protocol covid-19 health. Who do not have the facilities.

Lack of ability in use the facilities information technology and communication learning online based on data the questionnaire and interview dominated by students, but not necessarily all teachers as educators beat it. Learning with a system of online tending to dull and saturating because limited capability, ideas and creativity teachers in managing learning online.The limited space interaction and communication between teacher and students and among students with students of the other causes a loss of meaning learning active, creative, effective, and pleasing. Learning with a system of online also be a burden psychological for teachers and students. If they forced do what was actually they were yet ready to and have not been able to to do it. Pandemics covid-19 had changed everything including the world education in Rantau Panjang sub-district.

\section{Conclusions}

The results of research and discussion, then it is known that the implementation of online learning in primary school in Rantau Panjang sub-district length of the aspect of the context is very good. Many obstacles faced by schools from the aspect input in the implementation of online learning in primary school in Rantau Panjang sub-district. Overseas. The reporting on the implementation of online learning is already good. The implementation of online learning in primary school in Rantau Panjang sub-district overseas get a response that is less good and less satisfying than the principal, teacher, and students.

\section{References}

Hasanah, A., Ambar, SL., Alvin, YR., dan Yudi. 2020. Analisis aktivitas belajar daring mahasiswa pada pandemi Covid-19 [KTI]. Bandung (ID): UIN Sunan Gunung Djati.

Rachmat, A. dan Krisnadi, I. 2020. Analisis Efektifitas Pembelajaran Daring (Online) Untuk Siswa SMK $\begin{array}{lllllll}\text { Negeri } & 8 & \text { Kota } & \text { Tangerang Pada } & \text { Saat }\end{array}$ http://www.academia.edu/download/63479888 /Analisis_Efektifitas_Pembelajaran_Daring_ONLINE_pada_saat_Pandemi_COVID_192020053 1-66941-1ej1fmy.pdf (akses tanggal 17 Juli 2020)

Putria, H., Maula, L. H., dan Uswatun, D. A. 2020. Analisis Proses Pembelajaran Dalam Jaringan (daring) Masa Pandemi Covid-19 Pada Guru Sekolah Dasar. Jurnal Basicedu. 4(4):861-870. 
